原著：

静止画像伝送システムによる術中迅速病理診断の有用性

\author{
吉 岡 孝 行*, 武島 幸 男 ${ }^{2 *}$, 児玉 博 子*, 瀬戸恵利子*, \\ 西阪 隆 ${ }^{2 *}$, 井内 康 輝 $^{2 *}$, 土井謙 司 ${ }^{3 *}$, 大徳邦 彦 ${ }^{3 *}$
}

静止画像伝送システムを用いた術中迅速病理診断を試みた。使用した機器は猪原商会と NTT が共同して開発した "医用画像ネットワークシステム（テレパソロジー）" である。 1995年 4 月から 12 月までの間に63件の症例でこのシステムを利用した術中迅速病理診断を 行った。検討した症例は胃癌21例, 結腸癌13例, 乳腺腫瘍 5 例, 肺腫瘍 4 例, 甲状腺腫瘍 5 例, 卵巣腫瘍 3 例などである。提出された組織はリンパ節44例, 切除材料の断端部 20 例, 腫瘍組織13例であった。正診率は93.7\%と高く，また標本作成過程の改良によって診断ま での時間の短縮を見た。問題点としては低倍率の画像が芳しくない点，利用する病理関係 者の技術的あるいは病理学的知識が問われる点などが挙げられた。今後，画像伝送の技術 革新による，多方面への応用が期待される。
(1)静止画像伝送システム
(2)テレパソロジー
(3)迅速病理診断
(4)デジタル通信
(5)僻地医療

\section{緒言}

欧米と比較してわが国の病理医の数は慢性的 に不足して扣り，日本病理学会の認定病理医の 登録者数は平成 7 年 12 月現在 1,503 人と少なく, その分布も都市部に集中している ${ }^{1)}$ 。この為地 方の中小病院では, 大学の病理学教室, あるい は検査センターに委託して病理組織診断を行っ ている。術中迅速診断ではさらに深刻な問題を 生じることとなる。特に腫瘍の手術に際しては, 術前診断が確定されてない場合, 術中に腫瘍の 良悪性の判定や, リンパ節郭清の範囲や, 切除 断端部の決定といった，手術方針に直接関わる 情報を得る必要があるからである。

当院は広島市から約 $45 \mathrm{~km}$ 離れた中国山地

* 厚生連吉田総合病院病理研究検查科

$2 *$ 広島大学医学部病理学第二講座

3*厚生連吉田総合病院内科

（受付：1996年 4 月 8 日）
の農村地帯に位置し,さらに $20 \mathrm{~km}$ 北の山間部 に町の診療所を受託経営している総合病院で, 外来 11 科 (一日当たりの患者数 $700 \sim 800$ 人), 病 床数 365 床, 老人保健施設 60 床の典型的僻地中核 病院である ${ }^{2)}$ (図 1 )。従来, 術中迅速診断は病 理医の来院時に合わせて手術を行ったり, 近く

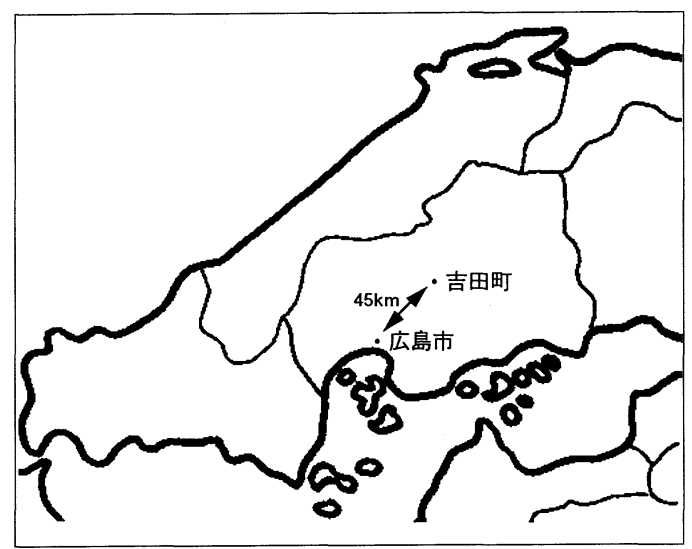

図 1. 広島市と吉田町の位置関係 直線距離で約 $45 \mathrm{~km}$ の距離がある。 
の病理医の常勤する病院に標本を運んで診断を 仰ぐ等で急場をしのいでいたが，緊急時や提出 標本数の多い場合はその対処に苦慮する場合が あった。やむを得ない場合は外科医の判断に 頼って手術を行っていた。

当院では昨年度より広島県の僻地中核病院運 営事業の一環として静止画像伝送システムによ る迅速病理診断を試行的に開始し2), その有効 性が認められたので, そのシステムの概要, シ ステムを用いた診断結果, 执よびその問題点に ついて報告する。

$$
\text { 方法 }
$$

\section{1. システムの概要}

静止画像伝送システムは数社から既に販売さ れているが ${ }^{3 \sim 6)}$, その低価格性と機能性より猪原 商会（広島市）とNTT が共同して開発した病 理診断システム "医用画像ネットワークシステ

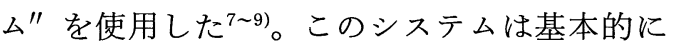
NTT 社製の Integrated Services Digital Net-
work（ISDN）回線を使用し，これに静止画像 伝送装置, 高精細カラーモニター, 生物顕微鏡 とそれに取り付ける CCD カメラ, 臟器撮影用 $\mathrm{CCD}$ カメラ, 画像データ保存用光磁気ディスク ドライブ，通話用スピーカーホン，ファクシミ リからなる。ISDN 回線は一秒間に 64 キロビッ トの情報を伝達するチャンネルを 2 本と16キロ ビットの信号チャンネルを 1 本を持つ高速デジ タル回線で音声と画像を同時に送信できる。画 像通信装置 (VM-64) は NTSC (National Television System Committee) 方式で, 精細 画像 $(768 \times 494$ 画素) の伝達速度は約 12 秒であ る。モニターはソニー社製の PVM-1442Q を使 用した。 $\mathrm{CCD}$ カメラは同じくソニー社製の XC -999を Nicon 社製顕微鏡に接続した。またマク 口の画像の撮影にも使用した。画像のデータの 保存には三菱化成社製の MK-1280の光磁気 ディスクを用いた。一枚のディスクに保存でき る画像は白黒画像で約 2,000 画像, カラー画像で 約1,000画像である。これらのシステムの概要を

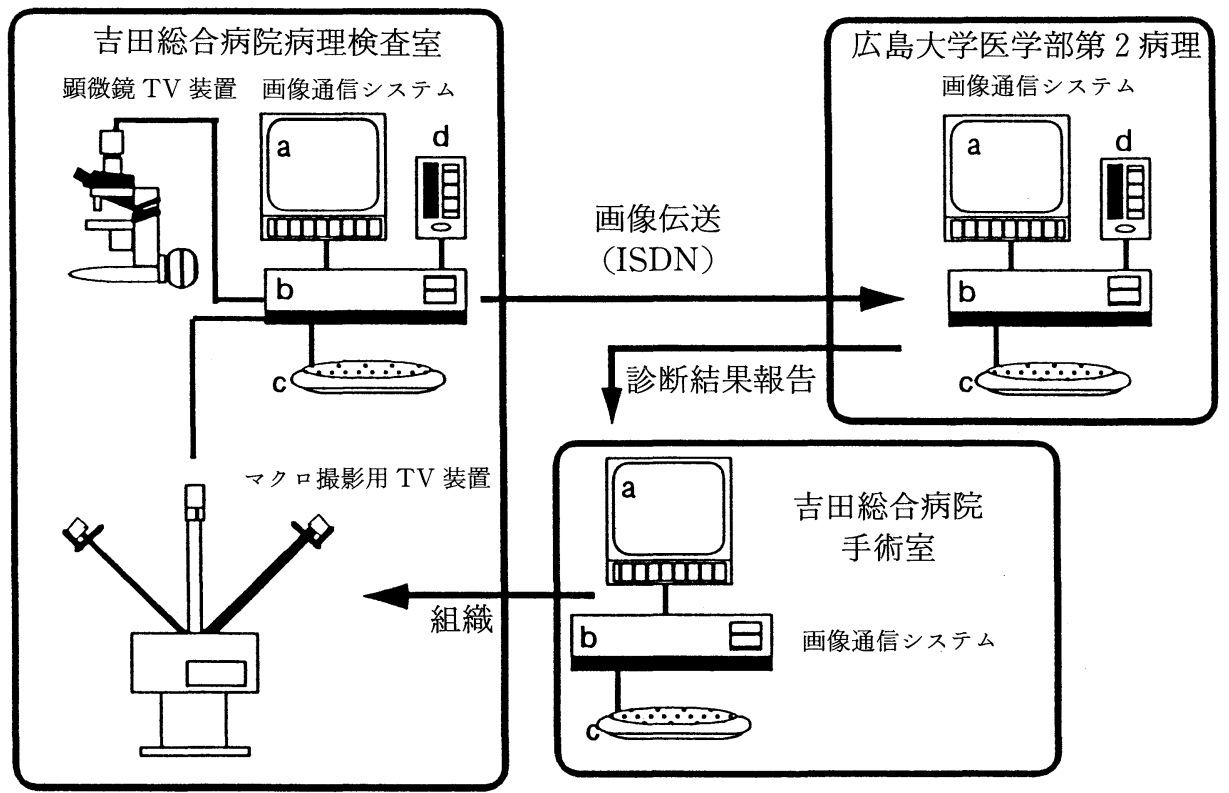

図 2. システム構成及び運用形態

病理検査室と広島大学間, 広島大学と手術室間はISDNによって結ばれる。診断報告は直接音声で報告で きるが，ファクシミリによる伝送も同時に行う。

$\mathrm{a}$ ：高精細カラーモニター, d : 画像データ保存用光磁気ディスク装置, b : 静止画像伝送装置, $\mathrm{c}$ ：通 話用スピーカーフォン。 
図 2 亿示す。手術室, 病理検査室, 病理学教室 間はそれぞれISDN 回路で連結し，リアルタイ ムで音声のやりとりが可能である。また術者に 画像を示しながら説明も可能である。また病理 医は病理検査室から送られてきた画像について 矢印で拡大部位を指定することが出来る。提出 された材料が大さい場合には，撮影台に取り付 けた CCD カメラで蔵器の肉眼像の映像を取り 达み，大学に伝送して切り出し部位の指示を受 けた。臟器がリンパ節等の小型な場合はその最 大割面を切り出し標本を作製した。検査依頼書 並びに報告書の送信にはファクシミリを使用し た。

\section{2. 標本作製法}

迅速な診断の為には，標本作製に必要な時間 を可能な限り削減寸るとともに, 永久標本之同 等となるような標本の質の向上が必要である。 $\mathrm{H} \& \mathrm{E}$ 染色標本の作成にはミクロトーム・クリ オスタット（マイルス三共社製）を使った。従 来の標本作製は組織をクリオモルド（プラス チック製包埋皿) に入れ，これにOCT コンパウ ンド（凍結組織標本作製用包埋剂）を注入し， この上にオブジェクトホルダー（金属製ブロッ ク台）を乗せる。これをクリオスタットのコー ルドバーの部分に装着し，その上から金属製の 重りを載せて冷却する。この方法では標本作製 の為に約 10 分の時間が必要である。一方, 当院 ではクリオモルドで使わず，直接オブジェクト ホルダーに OCT コンパウンドを少量盛り，そ
の上に組織を乗せコールドバーに装着する。こ れに冷却剤としてクライオエアゾールを噴射し 冷却した後, 従来通り薄切し $\mathrm{H} \& \mathrm{E}$ 染色を施す。 本方法ではアーチファクトの少ない良好な標本 作成が可能であり，かつ標本作製時間は平均約 5 分と従来法と比較して標本作製時間を約 5 分 短縮できた。また必要に応じて迅速 PAS 染色 を行った（図 3 )。

$$
\text { 結果 }
$$

平成 7 年 4 月から 12 月末までに，本システム を用いて63件の迅速術中病理診断を行った。そ の全手術数 (外科, 整形外科, 産婦人科) 飞対 する割合は $10.0 \%(63 / 631)$ である。その臨床 䛦断は多いものから, 胃癌 21 例, 大腸直腸癌 13 例，乳腺腫瘍 5 例，肺腫瘍 4 例，甲状腺腫瘍 5 例，卵巣腫瘍 3 例などとなっている(表 1 )。ま た検査の種類別では，断端部の悪性腫瘍の浸潤 の有無を問うものが20例，リンパ節転移の有無 を問うものが44例，腫瘍の組織診断を問うもの が13例であった。(一症例中で重複があるため総 計は63より多い) 京た一症例当たりの提出組織 数は 1 個から 4 個に及んだ。標本提出から診断 の報告までの時間は平均 20 分であった。診断の 妥当性は凍結標本を作成した組織を，フォルマ リン固定後に永久標本を作製して評価した。そ の結果，正訬率は93.7\%（59/63）と良好であっ た。診断に間違いがあった症例の内，2 例はり ンパ節の転移を問う症例であったが，これらは

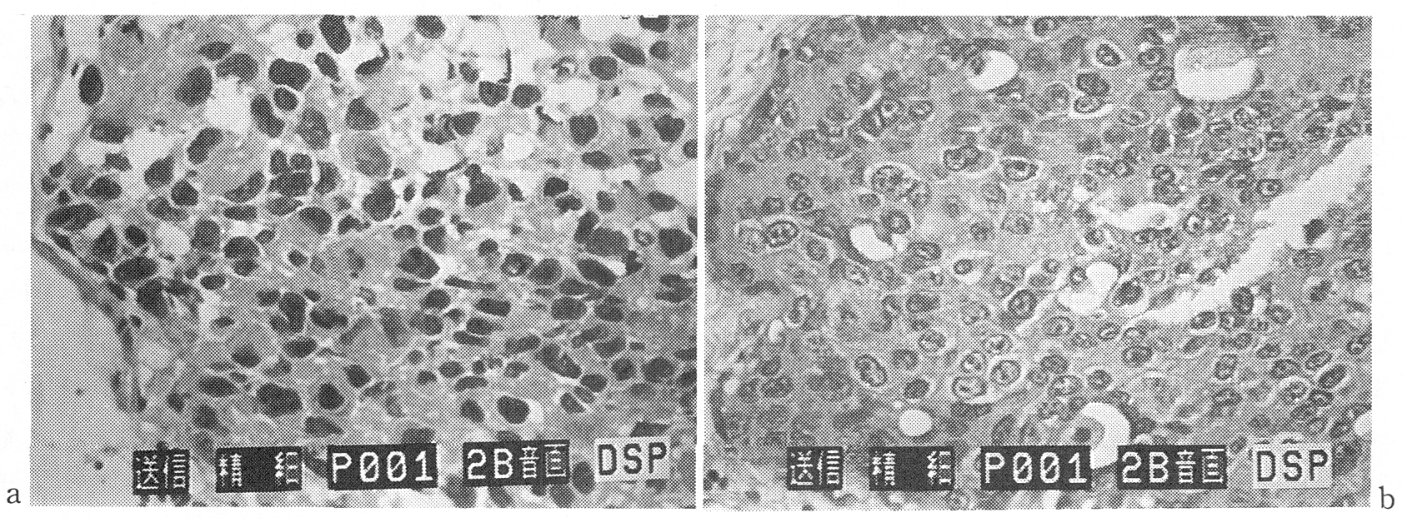

図 3。迅速標本(a) と永久標本(b)の H \& E 染色像 胃癌切除断端部の癌腫の浸潤像は，迅速標本でも十分な診断が可能である。 
表 1. 臨床診断別症例数と正診率

\begin{tabular}{|c|c|c|}
\hline & 症例数 (例数) & 正診率 \\
\hline 胃癌 & 21 & $90.4 \%$ \\
\hline 結腸癌 & 13 & $100 \%$ \\
\hline 乳腺腫瘍 & 5 & $100 \%$ \\
\hline 甲状腺腫瘤 & 5 & $60 \%$ \\
\hline 肺腫瘍 & 4 & $100 \%$ \\
\hline 卵巣腫瘍 & 3 & $100 \%$ \\
\hline 胆囊炎 & 2 & $100 \%$ \\
\hline 出血性胃潰瘍 & 2 & $100 \%$ \\
\hline 腹腔内腫瘤 & 2 & $100 \%$ \\
\hline 副腎腫瘍 & 1 & $100 \%$ \\
\hline 膵腫瘍 & 1 & $100 \%$ \\
\hline 転移性脳腫瘍 & 1 & $100 \%$ \\
\hline 急性虫垂炎 & 1 & $100 \%$ \\
\hline 尿管狭窄 & 1 & $100 \%$ \\
\hline 胸椎圧迫骨折 & 1 & $100 \%$ \\
\hline 計 & 63 & \\
\hline
\end{tabular}

いずれも永久標本作製時の面出しによって新た に現れた病変であった。また甲状腺腫瘍は濾胞 状腺腫と濾胞腺癌の鑑別, 腺腫性過形成と乳頭 状腺癌の鑑別に苦慮する症例が各 1 例づつあ り, これら 2 例は診断保留とした。また不適切 な部位の提出によって診断が極めて困難であっ た症例（いずれも乳腺腫瘤）が 2 例あったが, いずれも追加組織の提出により正しい診断を得 ることが出来た。

当院の術中迅速病理診断の依頼件数は1993年 8 件，1994年37件，1995年68件（本格運用前の 症例および実際に検鏡した診断した 5 件を含 む）と飛躍的な増加を示した。

\section{考察}

最近の画像機器および情報伝送法の発達によ り, 種々の画像が遠隔地に短時間の内に伝送す ることが可能となってきた。病理組織診断の画 像についても例外でなく，日本のいくつかの施 設で既に運用が開始されている ${ }^{3 \sim 9)}$ 。当院でも 1994年 4 月頃より，前述のシステムに注目して 術中迅速病理診断 ${ }^{2}$, CT スキャン画像や患部の X線画像を専門医に伝送して診断を受ける体 制10)を整えはじめた。

前述の如く本システムの有効性はその正診率 の高さ, 検体数の増加率, 迅速性, 廉価性の点
から実証されたが，同時にいくつかの問題点が 指摘された。

一つは画質の問題である。低倍率像が必ずし も良好でなく，拡大指定部位に苦慮することが あった。しかし，これは組織診の基礎的知識を 持った病理検査担当の細胞検査士による検鏡に よって適切な病変部位を指定することが可能 で，それによる誤診はなかった。また通常の検 鏡作業では "弱拡大での検鏡", “拡大による検 鏡", “視野の移動" "弱拡大での再検鏡", “強拡 大での再検鏡" の繰り返しが瞬時に行われるの に対して，本システムでは画像送信のみでも約 12秒を要し，その煩雑さが否めない。しかし， 症例を重祆るに従ってその操作性をあまり苦慮 することなく, 診断作業が行えるようになった。 このようにこのシステムの稼働にはある程度の 経験が必要であり，実際の運用を開始する前に 十分なトレーニングが必要である。また標本の 送り手に基本的な病理学的知識が要求されるの で, 日頃の業務の中で病理医の細胞検査士に対 する教育やコミュニケーションの必要性が重要 であることは言うまでもない。また本システム では画像を用いて臨床医と詳細なコミュニケー ションを取ることが可能であり，これは正確な 術中迅速診断に極めて有用な点でもある。今後, 日本国内の光ファイバーケーブル網や衛星通信 網がさらに充実すれば，現在の静止画像による 診断は “動画"による画像のやりとりが可能と なり, 実際の病理診断の作業感覚と類似したも のとなろら。

もら一つの問題点としては大型の材料, 例兄 ば胃癌摘出時の口側断端, 肛門側断端のような 材料に関しては，このシステムを利用して全視 野を観察するには相当な時間を要する点であ る。しかし，細胞検査士による直接の検鏡によ る適切な病変部位の特定によってこれは解消で きた。このような細胞検査士もいない場合には, 提出する材料の大きさを比較的小型にしてもら らことや，術者に肉眼的に十分な観察をしても らい, 必要最少量の組織の提出を促すことも重 要である。特に胃の印環細胞癌や低分化腺癌の 壁内浸潤の有無は実際の検鏡でも時に診断に苦 
慮することがあるが，今回経験した症例のうち 1 例で迅速 PAS 染色を行い, 浸潤の有無を確 認することが出来た。標本作製の更なる改良や 術中迅速細胞診 ${ }^{11}$ などの応用によって正診を得 る努力も必要である。

患者プライバシーの保護も重要な問題であ る。病理組織標本から得られる情報は患者の生 死や予後を判定する上で重要な情報となるの で, 実施にあたっては十分な配慮が必要である。 さらに画像といら媒体から病理診断を行う際の 法的責任の所在も明らかにしていく必要があろ 万。

今後の展望としては細胞診, 組織標本の診断 への応用, さらに病理医間, 細胞検査士と病理 医間，細胞検查士間でのコンサルテーションシ ステムの確立が挙げられる。これによって難解 症例の診断や, 細胞検查士, 病理医の研鑽の一 助となろう。また病理組織像といら情報のファ イリングシステムが充実すれば，これらの情報 が医学研究や教育へ貢献することとなろら ${ }^{12)}$ 。 また専門医のいない過疎地域の病院でもこのシ ステムを用いれば都市部と同様な精度を持った 診断を得られることから，患者の都市部への流 出に歯止めがかかり, 病院経営の改善への貢献 にも期待がもたれる。

\section{ま と め}

静止画像伝送システムを用いた術中迅速病理 診断の概略, 診断結果, 問題点について述べた。 今後, 症例数の蓄積により本システムの有用性, 問題点がさらに明らかにされ，システムの改良
の一助になることを期待する。本稿の内容は第 44回日本農村医学回総会にて報告した。

\section{文献}

1）日本病理学会会報 $1996,111: 1-5$.

2) 吉岡孝行, 清上浩明. 僻地でもリアルタイムで病理 診断. 文化連情報1995；212:26-29.

3 ）松本武夫, 児玉哲郎, 山岸紀美江. テレパソロジー システムの細胞への応用一画像を用いた精度管理 の必要性. 日本臨床細胞学会雑誌1994；33：351.

4) 新井 茂. テレパソロジー. 臨床病理 $1994 ; 42 ： 7$.

5) 山下 潔, 清水 薫, 原 正道ら. 病理医不在施設 からの画像层送システムを用いた迅速診断の可能 性についてーPATHTRAN1000を用いて一。 日本 病理学会誌 $1992 ; 81: 165$.

6) 野島孝行, 藤田美利, 藤岡保範ら. 遠隔地病院との 電話回線に上る術中迅速病理診断の試み. 日本病理 学会誌 $1993 ; 82: 164$.

7 ）谷山清己, 佐々木な和み, 前田雄司ら. ISDN 回線 とVM-64を用いた遠隔迅速病理診断の試み一廉価 システムの提唱一広島医学 $1994 ; 47 ： 1145-1148$.

8 ) 安達博信, 井藤久雄, 五明良化ら. 静止画像伝送ファ イリングシステム（テレパソロジー）による組織及 び細胞診断の経験. 鳥取医学雑誌1994; 22 : 219-222.

9）井藤久雄. テレパソロジーの時代. 日本臨床細胞診 学会 細胞検査士会会報1994；19：1-2.

10）清上浩明, 中村晃司, 小野尚且ら. 静止画像伝送シ ステムによる CT 読影診断の有用性. 日本農村医学 会雑誌 $1995 ； 44 ： 497$.

11）森谷卓也, 真鍋俊明, 伊禮 功ら. 乳腺疾患の術中 迅速診断に打㳊細胞診の有用性. 病理と臨床 $1994 ; 12: 719-723$.

12）井内康輝. 遠隔病理診断（テレパソロジー）の現状 と将来の展望。日本顎口腔機能学会第 7 回学術大会 抄録1994, 4-5. 


\title{
The Usefulness of Still Image Transmission System in Surgical Pathology
}

\author{
Takayuki YOSHIOKA*, Yukio TAKESHIMA*, Hiroko KODAMA*, Eriko SETO*, \\ Takashi NISHISAKA ${ }^{2 *}$, Kouki INAI ${ }^{2 *}$, Kenji DOI $^{3 *}$ and Kunihiko DAITOKU ${ }^{3 *}$
}

We have tried surgical pathologic diagnosis using a still image transmission system. The equipment we used was a medical information network system (Telepathology) developed jointly by Inohara Shokai and NTT. During the 9-month period from April to December in 1995, we performed pathological diagnosis on a total of 63 cases received via this system. The cases included 21 stomach cancers, 13 colorectal cancers, 5 breast tumors, 4 lung tumors, 5 thyroid tumors and 3 ovary tumors. Materials presented for pathologic examination were 44 lymph nodes, 20 stumped sections of the lesions and 13 tumor tissues. The correct diagnosis ratio was as high as $93.7 \%$. Improvement in the specimen-making procedure reduced the time required to arrive at a firm diagnosis. However, the quality of images of low magnification is unsatisfactory. It should also be pointed out that there is much room for improvement in the technical skill and knowledge of the persons concerned. Nevertheless, great expectations could be placed on this system. With progress in data transmissions technology, it will find its use more widely.

* Department of Pathology, Yoshida General Hospital

2* Second Department of Pathology, Hiroshima University School of Medicine

3* Department of Medicine, Yoshida General Hospital 